\title{
Adenomatoid odontogenic tumor simulating periapical cyst: case report
}

\author{
Tumor odontogênico adenomatóide simulando cisto periapical: relato de caso clínico
}

Francisco Paulo Araújo MAIA ${ }^{1}$

Priscilla Sarmento PINTO²

Anibal Henrique Barbosa LUNA²

\begin{abstract}
The adenomatoid odontogenic tumor is a benign, non-invasive tumor and has a slow growth. Its preferred location is the anterior maxillary area, most often causing root displacement, more rarely resorption and mostly affects young women. Being asymptomatic, this injury is discovered upon routine radiographic examination, in which, in most cases, a unilocular, radiolucent image is observed and it may have some degree of calcification within the lesion. This work aims to report the case of a 14-year-old patient who attended the Lauro Wanderley University Hospital (UFPB), complaining of increased volume over a period of 8 months, in the region of non-vital tooth 21. The CT scan showed well-delimited unilocular, radiolucent lesion, with buccal cortex resorption. The proposed treatment plan involved enucleation, followed by peripheral ostectomy and bone graft with alloplastic materials. Because of its benign character, encapsulated and slow growing, the treatment of choice for adenomatoid odontogenic tumor is conservative, the surgical enucleation of the injury being advocated. The excised piece was sent for histopathological analysis, where the AOT diagnosis was confirmed. After 7 months, new bone formation was observed without signs of recurrence.
\end{abstract}

Indexing terms: Maxilla. Oral pathology. Radicular cyst.

\section{RESUMO}

O Tumor Odontogênico Adenomatóide é um tumor benigno, não invasivo e de crescimento lento. Acomete principalmente mulheres jovens, na região anterior da maxila, causando na maioria das vezes deslocamento radicular e raramente reabsorção. Por ser assintomática, essa lesão é geralmente descoberta em exames radiográficos de rotina, no qual se observa na maioria dos casos uma imagem radiolúcida unilocular, podendo apresentar algum grau de calcificação no interior da lesão. Este trabalho tem como objetivo relatar o caso clínico de um paciente de 14 anos, gênero feminino, que compareceu ao Hospital Universitário Lauro Wanderley - Universidade Federal da Paraíba, com queixa de aumento de volume de 8 meses de evolução, em região de elemento 21 não vital. Ao exame tomográfico observou-se lesão radiolúcida, unilocular, bem delimitada, com reabsorção da cortical vestibular. O plano de tratamento proposto foi a enucleação seguida de ostectomia periférica e enxerto ósseo com material aloplásico. A análise histopatológica confirmou o diagnóstico de Tumor Odontogênico Adenomatóide. Após sete meses observa-se nova formação óssea e sem sinais de recidiva.

Termos de indexação: Maxila. Patologia bucal. Cisto radicular.

\section{INTRODUCTION}

The adenomatoid odontogenic tumor (AOT) is a not very common benign epithelial tumor, first described in 1907 by Dreibaldt as a pseudo-adenoameloblastoma', classified as an odontogenic tumor by the World Health Organization (WHO) in $1971^{2}$. In 2005, the WHO defined AOT as being composed of a variety of histological patterns of odontogenic epithelium embedded in conjunctive tissue stroma characterized by its slow, progressive growth ${ }^{3}$.

The AOT is usually an asymptomatic lesion. When it takes on larger proportions, it presents clinically with increased volume and a firm consistency on palpation. Displacement of adjacent teeth due to the growth of the tumor is more common than root resorption ${ }^{4}$.
The adenomatoid odontogenic tumor is a slowgrowing, benign and non-invasive lesion frequently discovered during routine radiographic examination ${ }^{5}$. The AOT has three clinicopathological variants: intraosseous follicular (pericoronal), intraosseous follicular (extracoronal) and extraosseous (peripheral) ${ }^{6}$. Normally, the radiographic characteristics present radiolucent, singlechambered lesions enfolding the crown of impacted teeth, although erupted teeth may also be found associated with this lesion.

The aim of this study is to report a case of AOT involving an erupted tooth that, due to its size, was treated during the diagnostic procedure (excisional biopsy), performing enucleation with peripheral ostectomy and a bone graft for alveolar reconstruction.

\footnotetext{
${ }_{1}$ Universidade Federal da Paraíba, Hospital Universitário Lauro Wanderley. Cidade Universitária, s/n., Campus I, Cidade Universitária, 58059-900, João Pessoa, PB, Brasil. Correspondência para / Correspondence to: FPA MAIA. E-mail: <fcopaulomaia@gmail.com>.

${ }^{2}$ Universidade Federal da Paraíba, Faculdade de Odontologia. João Pessoa, PB, Brasil.
} 


\section{CASE REPORT}

White, 14-year-old female patient came into the Oral and Maxillofacial Surgery Service of the Lauro Wanderley University Hospital (UFPB), complaining of increased volume in the region of the maxilla. Her historical record of the current disease reported the discovery of the lesion associated with tooth 21, non-vital, without pain, having evolved over 8 months. Endodontic treatment had been performed previously. In the intraoral physical examination, an increased volume, firm to the touch, and gingival hyperplasia was found in the region relating to tooth 21 (Figure 1).

The patient had undergone a tomographic examination of the region under another professional, which revealed a radiolucent image with a radiopaque halo measuring approximately $9.3 \mathrm{~mm} \times 1 \mathrm{~cm}$ at its largest diameter, causing partial resorption of the buccal cortex with displacement of adjacent teeth (Figure 2), and a preemptive orthodontic retainer was fitted to immobilize the teeth involved during the period of repair. An excisional biopsy was scheduled to clarify the diagnosis of the lesion and its definitive treatment. Aspiration biopsy revealed the absence of amber-colored liquid, thereby eliminating the possibility of it being a cystic lesion. The surgical treatment of choice was enucleation of the lesion by means of a trapezoid flap incision carried out in the region of elements $11,12,21$ and 22, followed by mucoperiosteal detachment (Figure 3) and ostectomy using a no. 6 surgical spherical bur (Beavers Dental ${ }^{\circledR}$, Morrisburg, Canada) with copious irrigation in a $0.9 \%$ sterile saline solution, conducted under local anesthetic. Having removed the lesion, a peripheral ostectomy was performed using a spherical diamond bur (KG Sorensen ${ }^{\circledR}$, São Paulo, Brazil) (Figure 4a). Given the defect in the portion of buccal bone resulting from the enucleation of the lesion, a graft was performed using lyophilized cortical bone (CORTBONE ${ }^{\circledR}$, João Pessoa, Brazil) (Figure 4b), and the operated region was sutured using Vicryl 4-0 absorbable thread (ETHICON ${ }^{\circledR}$, São Paulo, Brazil).

The histological cuts were examined under microscope, dyed using hematoxylin and eosin, and fragments were found of benign neoplasia of odontogenic origin, characterized by the proliferation of ductlike structures with a nodular, cribiform pattern (Figure 5a), as well as the deposition of basophilic structures consistent with osteodentine, added to the fibrous conjunctive tissue capsule with loose collagen fibers (Figure 5b), with a slight inflammatory infiltrate and slight vascularization, confirming the AOT diagnosis.
At the present time, the patient has completed 7 months since the surgery took place, noting the repair to the bone, normal probing depth with satisfactory gingival contours (figure 6a), and absence of any sign of recurrence in the routine radiographic examination (figure $6 b$ ).

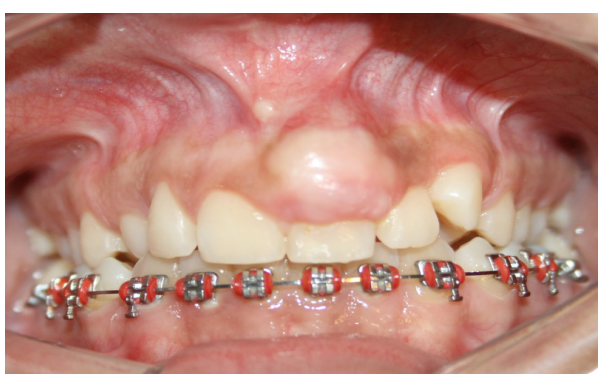

Figure 1. Pre-operative clinical appearance evidencing swelling in the region corresponding to tooth 21 .

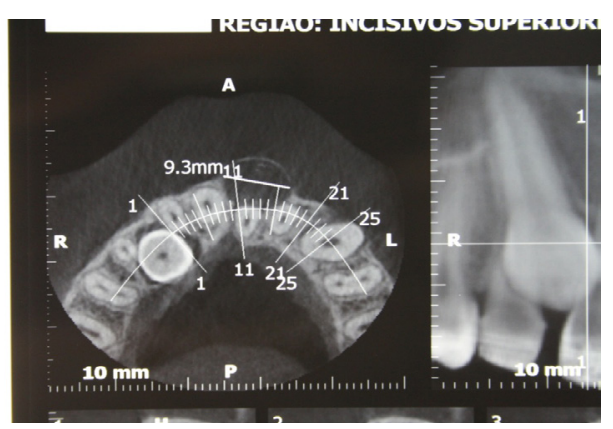

Figure 2. BCT with axial acquisition of the region involved. Note the integrity of the bone cortex, tooth displacement and dimensions of the lesion.

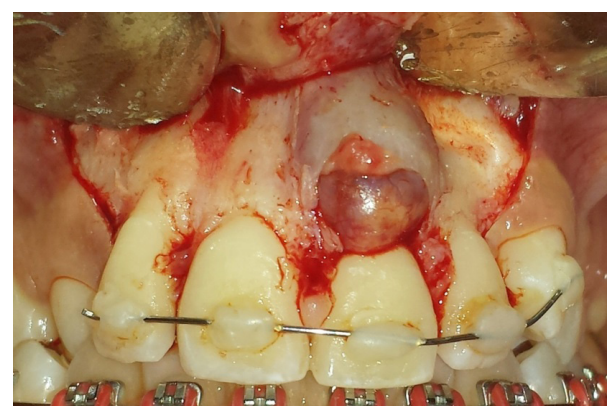

Figure 3. Mucoperiosteal detachment evidencing partial resorption of the buccal cortex, showing the lesion's potential growth

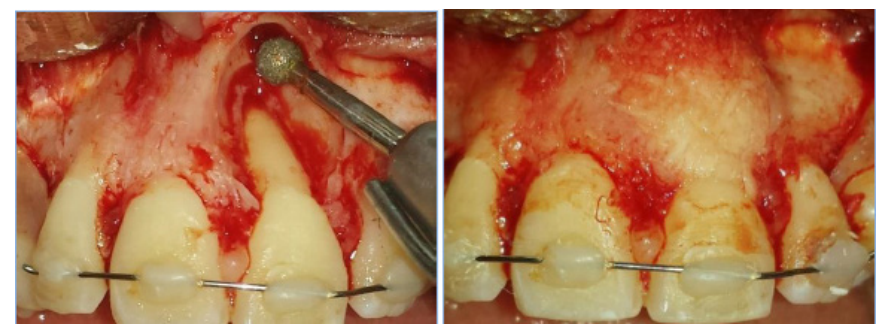

Figure 4. A) Bone defect after removal of the lesion and osteoplasty of the surgical cavity. B) Alveolar reconstruction with alloplastic materials. 


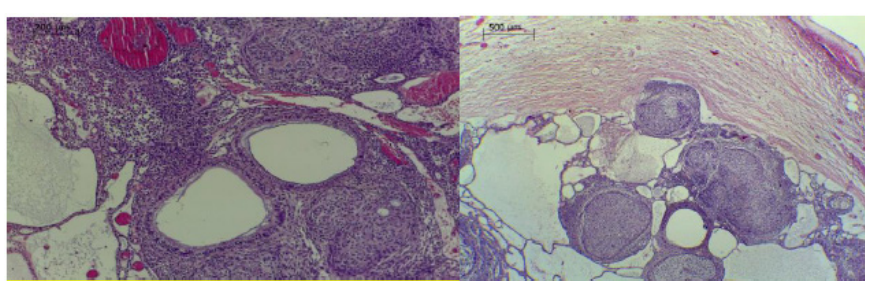

Figure 5. A) Larger increase, evidencing the presence of ductlike structures comprising columnar and cuboidal cells. Note the polarization of the columnar cell nucleus away from the central spaces. B) Smaller increase, evidencing a thick capsule of dense, fibrous, conjunctive tissue. Sparse, fibrous tumor-stroma.

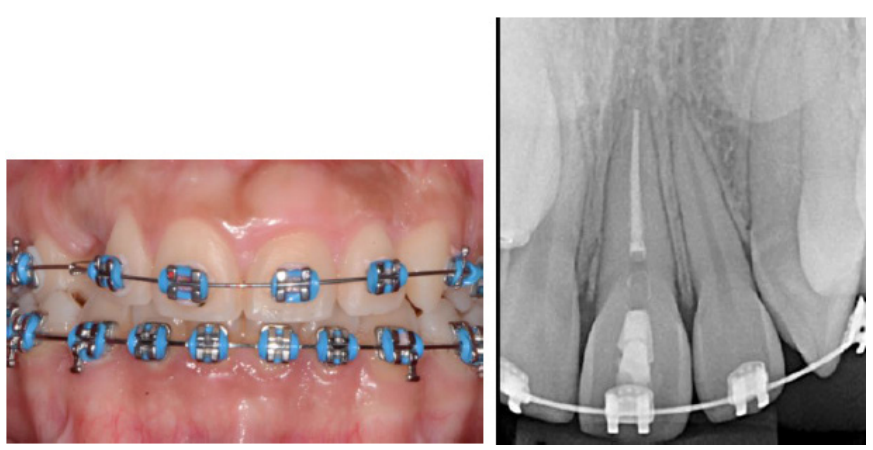

Figure 6. A) 7 months after surgery, evidencing the absence of periodontal defect and good gingival margin contours. B) Radiographic image 7 months after surgery, with no signs of recurrence.

\section{DISCUSSION}

AOT is a rare lesion, representing around $1.7 \%$ of all odontogenic tumors ${ }^{5}$.It has a preference for the maxillary anterior region, in roughly two-thirds of cases afflicting the anterior portion of the maxilla. It is usually associated with impacted teeth, most commonly the canine ${ }^{7-8}$. It mainly affects females, in a ratio of 1.9:1, and this preference is even higher in the Asian population, the highest incidence being in Sri Lanka (3.2:1) and Japan $(3: 1)^{9}$. As with all alterations, AOT often causes expansion of the involved bone and the displacement of adjacent teeth $^{10}$. In a study conducted by Chindasombatjaroen et al. (2012), $75 \%$ of cases presented with root displacement and $12.5 \%$ with resorption. These findings show that AOT most frequently causes root displacement and more rarely, resorption, corroborating the present study. It is important to emphasize that in this case the crown of tooth 21 remained in place. Root displacement was only detected in the tomographic examination, a finding that may not have been made using conventional radiography.

In a study conducted by Becker, which analyzed 272 cases of AOT between 1950 and 2010, follicular lesions represented $69 \%$ of all cases, extrafollicular $27 \%$ and the peripheral variant $5 \%$, and in the current case the variant found was of the extrafollicular type. As far as the radiographic characteristics are concerned, in $91 \%$ of cases a unilocular, radiolucent lesion was observed while only $3 \%$ were multilocular, and $77 \%$ of the lesions exhibited some degree of calcification. Chindasombatjaroen et al. (2012), in a retrospective study carried out between 2000 and 2011, reported that $67 \%$ of the cases presented radiopaque areas inside the lesion, which is not consistent with that presented in the case described.

The radiographic characteristics of AOT lead to a differential diagnosis with a variety of odontogenic lesions. The follicular variant is linked to the crown and often a part of the root of an impacted tooth, usually the upper canine and just occasionally the permanent molars. Accordingly it is often initially considered to be a dentigerous cyst based on a clinical and radiographic evaluation ${ }^{2}$. The keratocystic odontogenic tumor and the unicystic ameloblastoma are also similar to the follicular variant when located in the pericoronal region, however they are more common in the posterior region of the mandible, unlike $\mathrm{AOT}^{6}$, where it is more common in the anterior region of the maxilla. Given the endodontic history and being a small, incipient lesion not associated with an impacted tooth, the diagnostic hypothesis was a periapical cyst. Periapical cysts usually occur in non-vital teeth, presenting a certain degree of mobility as the lesion grows and with the displacement of adjacent teeth, associated with loss of lamina dura ${ }^{5}$. In a retrospective study conducted by Akinyamoju et al. ${ }^{11}$, the upper left central incisor was the tooth most affected in periapical lesions ${ }^{1}$, corroborating the diagnostic hypothesis of the present case.

The histological aspects of AOT, according to Neville et al. ${ }^{6}$, revealed a well-circumscribed lesion surrounded by thick, fibrous capsule, presenting with spindle-shaped epithelial cells forming structures similar to rosettes around a central area, whether or not filled with eosinophilic material. In a study carried out by Leon et al. ${ }^{5}$ which analyzed the histopathological characteristics of 39 lesions diagnosed as AOT, they observed that all the lesions had different rosette parts composed of cuboidal-shaped, epithelial cells, containing eosinophilic material, many of the lesions exhibiting calcified material, corroborating the histopathological findings found in the case described.

The adenomatoid odontogenic tumor has a low rate of recurrence, surgical enucleation of the lesion being the treatment of choice ${ }^{12}$. This is explained by the fact that AOT is usually delimited by a capsule of well- 
developed conjunctive tissue, and may be a solid mass, or have varying degrees of cystic degeneration. The presence of this capsule permits easy and complete removal, this being one of the factors that justifies conservative surgical treatment as the advocated treatment ${ }^{13}$. Nevertheless, the present case presented as a lesion that was small in size, indicating an excisional biopsy and leading to potential esthetic repercussions due to the periodontal defects. Moreover, not knowing the definitive diagnosis of the lesion, which presented with a perforation of the cortical bone and the need for osteoplasty to normalize the bone margins, a peripheral ostectomy was carried out to minimize the risk of possible recurrence. As this related to a diagnosis of AOT, a more conservative approach could be used without harm to the patient, as there is a low tendency towards recurrence. The enucleation of the lesion and the peripheral ostectomy resulted in an alveolar defect in the buccal region of tooth 21 , indicating a graft for

\section{REFERENCES}

1. John JB, John RR. Adenomatoid odontogenic associated with dentigerous cyst in posterior maxilla: a case report and review of literature. J Oral Maxillofac Pathol. 2012; 14(2): 59-62.

2. Phillips MD, Closmann JJ, Baus MR, Torske KR, Williams SB. Hybrid odontogenic tumor with features of ameloblastic fibroodontoma, calcifying odontogenic cyst, and adenomatoid odontogenic tumor: a case report and review of the literature. J Oral Maxillofac Surg. 2010 Feb;68(2):470-4. doi: 10.1016/j. joms.2009.04.118

3. Philipsen HP, Brin $\mathrm{H}$. The adenomatoid odontogenic tumor, ameloblastic adenomatoid tumor or adeno-ameloblastoma. Acta Pathol Microbiol Scand. 1969;75;375-398.

4. Taylor AM. New findings and controversies in Odontogenic tumors. Med Oral Patol Oral Cir Bucal. 2008;13(9):555-8.

5. Leon JE, Mata GM, Fregnani ER, Carlos-Bregni R, de Almeida OP, Mosqueda-Taylor A, et al. Clinicopathological and immunohistochemical study of 39 cases of Adenomatoid Odontogenic Tumour: a multicentric study. Oral Oncol. 2005 Sep;41(8):835-42.

6. Neville BW, Damm DD, Allen CM, Bouquot JE. Oral and maxillofacial pathology. 2nd ed. Philadelphia: WB Saunders; 2012.

7. Garg D, Palaskar S, Shetty VP, Bhushan A. Adenomatoid odontogenic tumor-hamartoma or true neoplasm: a case report. J Oral Sci. 2009 Mar;51(1):155-9.

8. Baskaran P, Misra S, Kumar MS, Mirthra R. Adenomatoid Odontogenic Tumor-A Report Of Two Cases with Histopathology Correlation. J Clin Imaging Sci. 2011;1: 64. reconstruction and better esthetic and functional results.

\section{CONCLUSION}

AOT is a slow-growing, benign lesion which is usually discovered during routine radiographic examination and, due to its fibrous capsule, may be easily enucleated from the bone, taking into account the best treatment option, recurrence being rare after enucleation. Control $x$-rays are performed to observe the new bone formation and the absence of recurrence.

\section{Collaborators}

FPA MAIA, case surgeon and manuscript author. PS PINTO, case assistant and manuscript author. AHB LUNA, lecturer supervising the case and manuscript reviewer.

9. Neville BW, Damm DD, Allen CM, Bouquot JE. Oral and maxillofacial pathology. 3rd ed. London: Saunders, Elsevier; 2009.

10. Batra P, Prasad S, Parkash H. Adenomatoid odontogenic tumour: review and case report. J Can Dent Assoc. 2005 Apr;71(4):2503.

11. Akinyamoju AO, Gbadebo SO, Adeyemi BF. Periapical lesions of the jaws: A review of 104 cases in Ibadan. Ann lb Postgrad Med. 2014 Dec;12(2):115-119.

12. Nigam S, Gupta SK, Chaturvedi KU. Adenomatoid odontogenic tumor - a rare cause of jaw swelling. Braz Dent J. 2005;16:251253. doi: 10.1590/S0103-64402005000300015

13. Philipsen HP, Nikai H, Barnes L, Eveson JW, Reichart P, Sidransky D. Adenomatoid odontogenic tumor. In: Barnes L, John W. Eveson JW, Reichart P, Sidransky D. Pathology and genetics of head and neck tumors. Lyon: IARC Press; 2005. p. 304-305. 